\title{
The Ecology and Conservation of Wild Rice, Zizania palustris L., in North America
}

\author{
Ecologia e Conservação do Arroz Selvagem, Zizania palustris L., na América do Norte
}

\section{David Dean Biesboer (iD}

${ }^{1}$ Department of Plant and Microbial Biology, University of Minnesota, 5620 Mahoney Avenue, 55345, Minnetonka, MN, USA

e-mail: biesboer@umn.edu

Cite as: Biesboer, D.D. The Ecology and Conservation of Wild Rice, Zizania palustris L., in North America. Acta Limnologica Brasiliensia, 2019, vol. 31, e102.

Abstract: Wild rice is an enigmatic plant species in the upper northern Midwestern U.S. Wild rice (Zizania palustris L.) is widespread in the region. However, it is both a wild species and a semi-domesticated crop. It is enigmatic because it is grown and harvested by machine in large paddies by commercial farmers but wild populations are considered to be important spiritually to native Americans in the United States. Native Americans and the public harvest wild rice by hand and sell and trade it on a local basis. This has caused a political controversy between people who consider wild rice to be a crop belonging only to native Indian bands and those who consider that it belongs to citizens of the U.S. Conservation of populations of wild rice has become politically difficult because of these contrasting views. This paper discusses this controversy and addresses the difficulty of conserving this economically widespread plant that is under ecological pressure in modern times.

Keywords: Zizania; Wild Rice; semi-domesticated; North America; restoration; conservation.

Resumo: O Arroz selvagem é uma espécie de planta enigmática da parte do centro-norte dos EUA. O arroz selvagem (Zizania palustris L.) é encontrado em muitos locais nessa região. Contudo, é uma espécie selvagem, mas ao mesmo tempo produzida de forma semi-domesticada. É uma planta enigmática porque é produzido e colhido em grandes alagados por fazendeiros comerciais, mas populaçóes selvagens são consideradas cultural e espiritualmente importantes para as comunidades de Americanos-Nativos nos EUA. Tanto os Americanos-Nativos quanto o público em geral colhem o arroz selvagem manualmente e vendem no comércio local. Isso tem causado controvérsias entre as pessoas que consideram que o arroz selvagem pertence a cultura indígena nativa e as pessoas que consideram que pertence a todos os cidadãos dos EUA. Por causa dessas visões contrastantes, a conservação desta espécie é politicamente muito conturbada. Esse artigo discute essa controvérsia e aponta as dificuldades de conservaçáo dessa espécie de planta de amplo interesse econômico e que está sobre forte pressão ecológica nos tempos atuais.

Palavras-chave: Zizânia; Arroz Selvagem; semi-domesticado; América do Norte; restauração; conservaçáo. 


\section{Introduction}

Wild rice species (Zizania spp.) are emergent aquatic macrophytes. Although not examined taxonomically in recent years, the genus is generally agreed to consist of four species, three North American and one Asian.

Zizania spp. have historical and modern value as a human food source. It is ecologically important as a wide spread wetland species. In the state of Minnesota, USA, one species (Zizania palustris L.) has played an important cultural role for the Anishinaabe band of North American native peoples. Native peoples consider wild rice and lakes that produce rice to be sacred. Radiocarbon dating by McAndrews (1969) indicated that wild rice was used as a foodstuff in Minnesota at least $2450 \pm 100$ years ago.

Zizania palustris is a monetarily important annual, semi-domesticated plant found in the Upper Midwest of the USA and extending north into Canada. It grows in shallow lakes and slow moving rivers. In addition to $Z$. palustris, at least three other taxa are generally recognized as clearly distinct species in this genus. They include $Z$. aquatica L., a larger statured plant with a more branched panicle and smaller seed size that is found in the Great Lakes region and on the eastern seaboard (Grombacher et al., 1997). Zizania aquatica L. is not a harvestable species. Zizania texana Hitchc. is an endangered species restricted in distribution to only two populations in the Sand Marcos River of Texas. Zizania latifolia Griseb. is a disjunct species known as Manchurian wild rice because its native habitat is in Eastern Asia. The base of $Z$. latifolia can become infected with a fungus that is a delicacy in these areas. Zizania palustris and $Z$. aquatic occur sympatrically in some areas of the state of Minnesota (personal observation).

By law in Minnesota, wild rice found in lakes and rivers must be harvested by hand. But, in 1950, the first wild rice paddy was built (Grombacher et al., 1997). Thousands of hectares of wild rice are being cultivated in Minnesota, Wisconsin, and California and now contribute with millions of dollars to the national economy. This short review focuses on the North American species $Z$. palustris and, unless otherwise indicated, the term "wild rice" will be used to refer to this species. Minnesota has more hectares of naturally occurring wild rice than any other state in the USA.

\section{Life History and Ecology}

Naturally occurring stands occur principally in north and north-central Minnesota with populations extending into Canada and the western state of Wisconsin, USA.

Wild rice is a monoecious, annual wetland species. It grows best along lakeshores, in permanent wetlands, and along slow-moving rivers in loose, organic, flocculent sediments. Hydrologically, wild rice requires the presence of shallow, relatively clear water from a depth of 0.1 to $1 \mathrm{~m}$. The best sediments are organic muck at least several centimeters deep but I have observed wild rice populations growing on sandy or even marly lake bottoms. Wild rice prospers in aquatic systems that have some flowage, i.e., lakes with an inlet and outlet, or at the edge of rivers.

The phenology of wild rice is well known. It can be summarized as follows. The seed germinates in the spring when water temperatures reach about $5.6^{\circ} \mathrm{C}$. The first submerged leaves begin to appear in mid-May, about three weeks after the coleoptile emerges. Floating leaves can appear at the end of May. The plants are very susceptible to changes in water level at the floating leaf stage.

Aerial leaves appear in early to mid-June, about 10 days after the floating leaves first form. They are usually from $1-3 \mathrm{~cm}$ in width and can be up to $75 \mathrm{~cm}$ long. The plant stalk begins to grow above the water in early July. Wild rice can produce more than one stalk (tiller). Up to 50 tillers per plant can be formed in natural populations, however fewer are usually observed. Panicle development begins in early July on the most mature tillers, and flowering can last until mid- August. Seeds appear on the panicles of this aquatic grass in late August. Harvesting generally occurs in early September. The stands can be dense often forming monocultural populations.

\section{Conservation}

It is recognized that changes in hydrology of streams, lakes and rivers, changes in seasonal housing along lakeshores, changes in climate, pollution, and competition from both native and exotic aquatic species are threatening wild rice. Wild rice was common during the 18th century east of the Mississippi River but now is confined to the northern states of Minnesota, northern Wisconsin and small areas of Michigan. The most important threat is a loss of genetic diversity that is the direct result of the previously mentioned threats. As habitat declines, competition also increases from 
exotic species, forcing decreases in the size of native populations and their genetic diversity.

Perhaps the most important consideration for conserving or restoration of wild rice in Minnesota is the conservation of and/or the rebuilding of wild rice habitat. If wild rice is declining in a watershed, the reasons for its decline must be discovered. Populations are susceptible to (1) water pollution; (2) fluctuations in water levels that are man-made or caused by beaver dams; (3) competition from native weeds [such as Nymphaea spp. (water lilies), Typha latifolia L. (cattail) or Alisma triviale Pursh. (water plantain)]; (4) large boat wakes that erode shorelines and subsequently tend to favor establishment of cattails; (5) and physical removal of wild rice by land or resort owners that can severely impact local populations where wild rice is not abundant. Populations may also be impacted occasionally by a number of biological agents such as fungal diseases or insects, e.g, Apamea apamiformis Guenee (the rice worm). The importance of wild rice to Native Americans and its ecological role in wetland ecosystems as a food source for many wildlife species make the conservation of extant natural populations and preservation of their genetic variability a serious concern (Waller \& Lu, 2000).

Genetic variability has more recently been studied by Biesboer et al. (2011). Based on this latter genetic study, the following can be noted:

1) In a study of 70 wild rice lakes, it was determined that $Z$. palustris has a reasonable amount of genetic diversity. Individual populations of $Z$. palustris may vary in their dispersal rates and distances from other populations to which a specific population can interbreed. These differences in genetic diversity may correlate with life histories of specific populations. I note that the species colonized the state of Minnesota after the last glaciation that ended ca. 10,000 to 13,000 years before the present, ample time for this species to change genetically.

2) Value judgments must be made to determine if a restoration will be historically accurate or more broadly, only a functional one. Natural populations will experience genetic changes over time and space. However, as Falk et al. (2001) note, even where the emphasis is on a functional restoration, historic accuracy should be considered to anchor restoration attempts within the natural range of variability. Historical accuracy is also complicated by the fact that people have introduced wild rice to many lakes and rivers over time. This practice has occurred for many decades. It has been done locally many times by sportsmen introducing wild rice into ponds for waterfowl hunting, by local people who just desire to have wild rice in their lakes and ponds, and certainly by native people over much longer periods of time. Records of those introductions can rarely be verified. Additionally, waterfowl feeding in wild rice beds move seeds from one water body to many others.

3) Restorationists often use geographic distance from seed sources for establishing new populations (i.e., it seems to make sense to find a population in the same watershed not far from the restoration site). But it can be a crude substitute for patterns of gene flow among populations and may not reflect the genetics of the population being restored. If populations are strongly selected to local habitats, then habitat similarity may outweigh distance as a selection criterion. However, we often do not know how well a population is adapted to its habitat.

4) Large genetically diverse populations are generally preferable to small isolated populations as a source of seeds for restorations, even when those small populations are geographically closer to the restoration site. It is probably preferable to combine seed sources from several suitable sites to capture a wider array of genetic diversity that can succeed in the new location.

5) On the other hand, small, localized populations can be "swamped" by the introduction of genetically diverse seed sources. If an existing population is to be increased or augmented, the number of seeds from other locations should not be so large as to overwhelm the local genotype. In other words, some care must be taken in determining exactly which populations might be most suitable for introductions.

\section{Conclusion}

The conservation of wild rice in Minnesota has become a very important political consideration. Recently, the state governor appointed a wild rice task force to study wild rice and its conservation. This group included environmental advocates, regulators, scientists, representatives from mining industries and tribal members. This task force was formed to protect wild rice waters from sulfate pollution, a pollutant often released in surface 
waters by mining operations. This task force could not come to an agreement about how to regulate pollution of wild rice waters in Minnesota. I await more study of the conservation of wild rice in Minnesota.

\section{References}

BIESBOER, D.D., KAHLER, A.L. and KERN, A.J. Understanding threats, genetic diversity and conservation options for wild rice [online]. St. Paul: Minnesota Legislative Reference Library, 2011 [viewed 01 Ago. 2012]. Available from: http://www. leg.state.mn.us/lrl/lrl.asp_

FALK, D.A., KNAPP, E. and GUERRANT, E.O. An introduction to restoration genetics. Washington: Society for Ecological Restoration, 2001. Why is genetic diversity important? pp. 17-18.
GROMBACHER, A., PORTER, R. and EVERETT, L. Breeding Wild Rice. Plant Breeding Reviews, 1997, 14, 237-265.

MCANDREWS, J. Paleobotany of a wild rice lake in Minnesota. Canadian Journal of Botany, 1969, 47(11), 1671-1679. http://dx.doi.org/10.1139/ b69-243.

WALLER, D.M.Y. and LU, P.D. Population genetic variation among wild rice populations in northern Wisconsin. In: L.S. WILLIAMSON, L.A. DLUTKOWSKI and A.P. MCCAMMON SOLTIS, eds. Proceedings of the Wild Rice Research and Management Conference. Odanah: Great Lakes Indian Fish and Wildlife Commission, 2000.

Received: 23 January 2019 Accepted: 30 April 2019 